\title{
Ancient DNA identification of domestic animals used for leather objects in Central Asia during the Bronze Age
}

\author{
Oskar Schröder, ',2 Mayke Wagner, ${ }^{2}$ Saskia Wutke,' Yong Zhang, ${ }^{3}$ \\ Yingxia Ma, ${ }^{4}$ Dongliang $\mathrm{Xu},{ }^{3}$ Tomasz Goslar, ${ }^{5,6}$ Reinder Neef, \\ Pavel E Tarasov ${ }^{8}$ and Arne Ludwig'
}

\begin{abstract}
The arid climate of many regions within Central Asia often leads to excellent archaeological preservation, especially in sealed funerary contexts, allowing for ancient DNA analyses. While geneticists have looked at human remains, clothes, tools, and other burial objects are often neglected. In this paper, we present the results of an ancient DNA study on Bronze Age leather objects excavated from tombs of the Wupu cemetery in the Hami Oasis and Yanghai cemetery in the Turpan Oasis, both in Xinjiang Uyghur Autonomous Region of northwestern China. In addition to species identification of goat (Capra aegagrus/hircus), sheep (Ovis orientalis/aries), and cattle (Bos primigenius/taurus), mitochondrial haplogroups were determined for several samples. Our results show that Bronze Age domesticated goats and sheep from the Hami and Turpan oases possessed identical or closely related haplotypes to modern domestic animals of this area. The absence of leather produced from wild animals emphasizes the importance of animal husbandry in the cultures of Wupu and Yanghai.
\end{abstract}

\section{Keywords}

ancient DNA, goat, leather, sheep, Wupu, Yanghai

Received II December 20I5; revised manuscript accepted 25 February 2016

\section{Introduction}

Sheep, goat, and cattle were domesticated in the Fertile Crescent of southwest Asia at around 10,000 years ago (Tapio et al., 2006; Zeder, 2008), from where they spread across Eurasia, entering northwestern China about 6000-6800 years ago (Lv et al., 2015). Note that calendar ages are consistently used in this study, unless stated otherwise.

The 1st millennium BC graves of Wupu and Yanghai in the Hami and Turpan oases, respectively, of the Xinjiang Uyghur Autonomous Region have yielded well-preserved human mummies as well as tools, clothing, and other mortuary offerings (Beck et al., 2014; Guojia Wenwuju, 2012; Xinjiang tu lu fan xue yan jiu yuan and Xinjiang wen wu kao gu yan jiu suo, 2011). Their leather coats, bracers, and quivers provide a valuable tool for identifying the domesticated and wild animals, which were in human use during this time. Although some of the leather samples have been identified as sheep-derived before DNA studies, due to the presence of wool, other samples were heavily processed preventing a reliable wool/hair identification. Since the extremely arid taphonomic conditions of Xinjiang are favorable not only for leather but also for DNA preservation (Li et al., 2010, 2011), determining the species of origin using mitochondrial DNA genotyping is a promising approach.

Previously, DNA was extracted successfully from ancient leather and parchment samples in only a very few cases (Hofreiter et al., 2015; Poulakakis et al., 2007; Schlumbaum et al., 2010; Teasdale et al., 2015; Vuissoz et al., 2007). Tanning and dyeing during the processing of hides often heavily degrade DNA (Brandt et al., 2011; Vuissoz et al., 2007) or may even introduce contaminations using animal brains as a tanning agent (Schlumbaum et al., 2010). In this study, we used sequences of two mitochondrial genes cytochrome $b$ and control region to determine the species of origin and their mitochondrial haplogroup, addressing the biogeographic origin of animals.

\footnotetext{
'Department of Evolutionary Genetics, Leibniz Institute for Zoo and Wildlife Research, Germany

2Eurasia Department, German Archaeological Institute, Germany ${ }^{3}$ Academia Turfanica, P.R. China ${ }^{4}$ Hami Museum, P.R. China

${ }^{5}$ Faculty of Physics, Adam Mickiewicz University in Poznań, Poland ${ }^{6}$ Poznan Radiocarbon Laboratory, Foundation of the A. Mickiewicz University, Poland

${ }^{7}$ Department of Natural Sciences, German Archaeological Institute, Germany

${ }^{8}$ Section Paleontology, Institute of Geological Sciences, Free University of Berlin, Germany
}

\section{Corresponding author:}

Oskar Schröder, Department of Evolutionary Genetics, Leibniz Institute for Zoo and Wildlife Research, Alfred-Kowalke-Str. 17, 10315 Berlin, Germany.

Email: oschroeder@izw-berlin.de 


\section{Materials and methods}

\section{Sites and samples}

The Yanghai cemetery (Figure 1) is an archaeological site located in a present-day gravel desert (Jiang et al., 2006; Xinjiang tu lu fan xue yan jiu yuan and Xinjiang wen wu kao gu yan jiu suo, 2011) in the northeastern part of theTurpan (also known as Turfan) Oasis, c. $43 \mathrm{~km}$ southeast of the city of Turpan. The climate of this area is extremely continental, with cold dry winters, hot dry summers, and seasonal temperature amplitude of above $70^{\circ} \mathrm{C}$ (Domrös and Peng, 1988). Annual precipitation is below $50 \mathrm{~mm}$, everywhere outside the mountain ranges. The continual aridity ensures very good preservation of all types of organic materials, even over several millennia (e.g. Beck et al., 2014; Wagner et al., 2009). Archaeological excavation conducted at the Yanghai cemetery has shown that it is relatively large (about $54,000 \mathrm{~m}^{2}$ ) and was used for a long period, starting in $c$. 12th century BC until $c$. 2nd century AD (Kramell et al., 2014; Xinjiang tu lu fan xue yan jiu yuan and Xinjiang wen wu kao gu yan jiu suo, 2011). Excavations of the individual tombs have shed light on the subsistence strategy of the people buried there. However, to date only a handful of these data have been published (Beck et al., 2014; Jiang et al., 2006, 2007, 2009; Kramell et al., 2014).

The Wupu cemetery (Figure 1) is known mainly for its wellpreserved mummies (Wang, 1999). The site is named after Wupu village, located about $60 \mathrm{~km}$ west of Hami, an important oasis on the ancient Silk Road, northeast of the Tarim Basin. The dry continental environments around Wupu are similar to that of Yanghai.

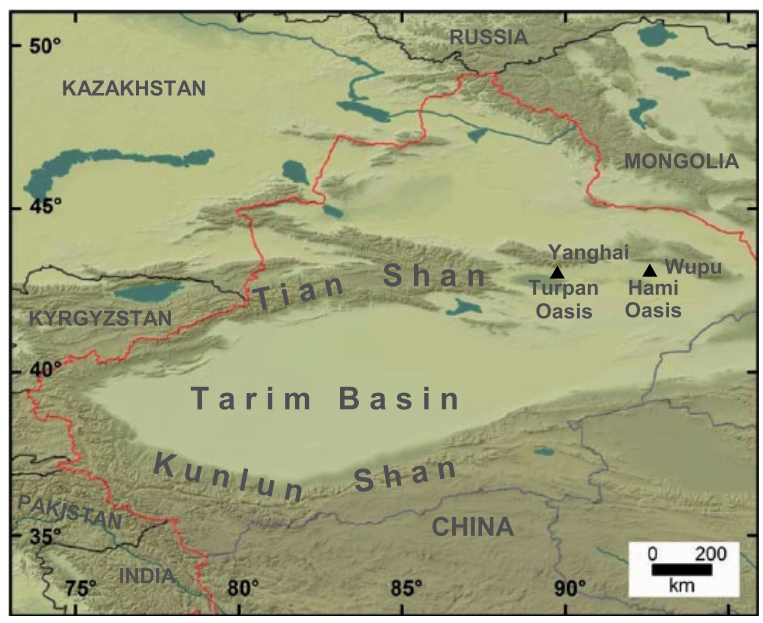

Figure I. Map showing the main physiographic features of the Xinjiang Uyghur Autonomous Region in northwestern China and the location of the Yanghai and Wupu archaeological sites northeast of the Tarim Basin.
The graveyard, consisting of 114 graves, was excavated during several campaigns (the last in 1991) by the archaeological team from the Hami Museum and revealed numerous mummies and artifacts assigned to the Bronze Age (c. 15th-8th century BC). Since a comprehensive excavation report has not yet been published, objects hosted in the museum partly lack a clear burial context and tomb identification.

Samples used for the DNA analysis were provided by Chinese cooperation partners representing the Chinese Academy of Cultural Heritage, Xinjiang Uygur Autonomous Region Bureau of Cultural Heritage, Xinjiang Institute of Archaeology, the Bureau of Cultural Relics of the Turpan Prefecture, and the archaeological museums in Hami and Turpan, which host archaeological objects from Wupu and Yanghai, respectively. In April 2013, leather artifacts were sampled for this study, within the framework of the Chinese-German Silk Road Fashion research project. In total, 10 selected samples (Table 1) represent one or two tombs from Wupu, excavated in 1986, and one tomb (M195) from Yanghai, excavated in 2003. The Wupu objects include two leather coats, sewn together from several smaller pieces of leather that were sampled separately with wool/hair still attached to the inner surface (Figure $2 a$ and $b$ ). Whether they were found in one or two tombs in the Wupu cemetery could not be established based on the excavation records. The Yanghai objects consist of two leather sheaths for a bow and arrows (Figure $2 \mathrm{c}$ and d) and a short leather bracer (Figure 2e). Short-living herbaceous plant remains (Table 2), associated with the leather fur coat number 86HWM:2-00752 from Wupu, were radiocarbon dated to 2515 \pm 30 (Poz-57373), 2480 \pm 30 (Poz-57371), 2470 \pm 30 (Poz57374 ), and $2465 \pm 30$ (Poz-57375) ${ }^{14} \mathrm{C}$ years before present (BP). Being converted to calendar years using the OxCal software (Bronk Ramsey, 2013) and IntCal13 atmospheric curve (Reimer et al., 2013), these dates translate to $762-541$ BC (95.4\% probability range of the four combined dates). The thread, with which the leather patches of coat number 86HWM:1-00751 were sewn together, was radiocarbon dated to $2500 \pm 30$ (Poz-72755) ${ }^{14} \mathrm{C}$ yr BP (i.e. $788-537 \mathrm{BC}, 95.4 \%$ probability). One of the leather samples analyzed in this study from tomb Yanghai M195 was radiocarbon dated to $2475 \pm 30$ (Poz-76927) ${ }^{14} \mathrm{C}$ yr BP. Calibrated to calendar years, this date represents the interval 771 $431 \mathrm{BC}(95.4 \%$ probability range). Our results suggest that the leather fur coats number 86HWM:2-00752 and 86HWM:100751 from Wupu and the tomb M195 objects from Yanghai represent broadly the same time interval at $c$. 8th to 5 th century BC (95.4\% probability range). The calibrated radiocarbon ages of the analyzed objects from Wupu are younger than the ages previously suggested by the excavators based on typological associations. However, three dates obtained on wood samples from other tombs (Table 2) demonstrate that the Wupu graveyard was already in use during much earlier times (i.e. 1409-806 BC) in

Table I. Leather sample data and sequencing results (cf. Figure 2).

\begin{tabular}{|c|c|c|c|c|c|c|c|}
\hline Collection number & Locality & $\begin{array}{l}\text { Archaeological } \\
\text { object }\end{array}$ & Sample ID & Animal species & Haplogroup & $\begin{array}{l}\text { GenBank accession } \\
\text { numbers }\end{array}$ & $\begin{array}{l}\text { Best match } \\
\text { (sequence identity) }\end{array}$ \\
\hline \multirow[t]{3}{*}{ 86HWM:I-0075 I } & Wupu & Leather coat & $|304| 4 / 24$ & Ovis orientalis & Sheep A & KU686। 63,70,76,83,87 & KR6I0959 (99\%) \\
\hline & & & $|304| 4 / 26$ & Ovis orientalis & Sheep intermediate $A / B$ & KU686I 64,7I,77,84,88 & JX235856 (100\%) \\
\hline & & & $|304| 4 / 28$ & Ovis orientalis & Sheep B & KU686 I65,72,78,85,89 & KROII 777 (100\%) \\
\hline \multirow[t]{2}{*}{ 86HWM:2-00752 } & Wupu & Leather coat & $|304| 4 / 33$ & Capra aegagrus & Goat A2 & KU686I66,73,79,90 & KP6775II (100\%) \\
\hline & & & $|304| 4 / 34$ & Capra aegagrus & Goat A3 & KU686|674,74,80,9। & KPI2068I (100\%) \\
\hline \multirow[t]{3}{*}{ 2003SAYIMI 95:9 } & Yanghai & Bow and arrow & $1304 \mid 7 / 82$ & Capra aegagrus & PCR fail & KU686I678I & KP6627I6 (98\%) \\
\hline & & sheath & $1304 \mid 7 / 83$ & PCR fail & PCR fail & & \\
\hline & & & $1304 \mid 7 / 84$ & Bos primigenius & PCR fail & KU686168,75 & KT260I 96 (98\%) \\
\hline 2003SAYIMI95:10 & Yanghai & $\begin{array}{l}\text { Bow and arrow } \\
\text { sheath }\end{array}$ & $|304| 7 / 85$ & Ovis orientalis & PCR fail & KU686169 & KT78I689 (100\%) \\
\hline 2003SAYIMI95:I2 & Yanghai & Leather bracer & $1304 \mid 7 / 87$ & Ovis orientalis & Sheep Ala (not repeatable) & KU686I82,86 & KF302440 (100\%) \\
\hline
\end{tabular}




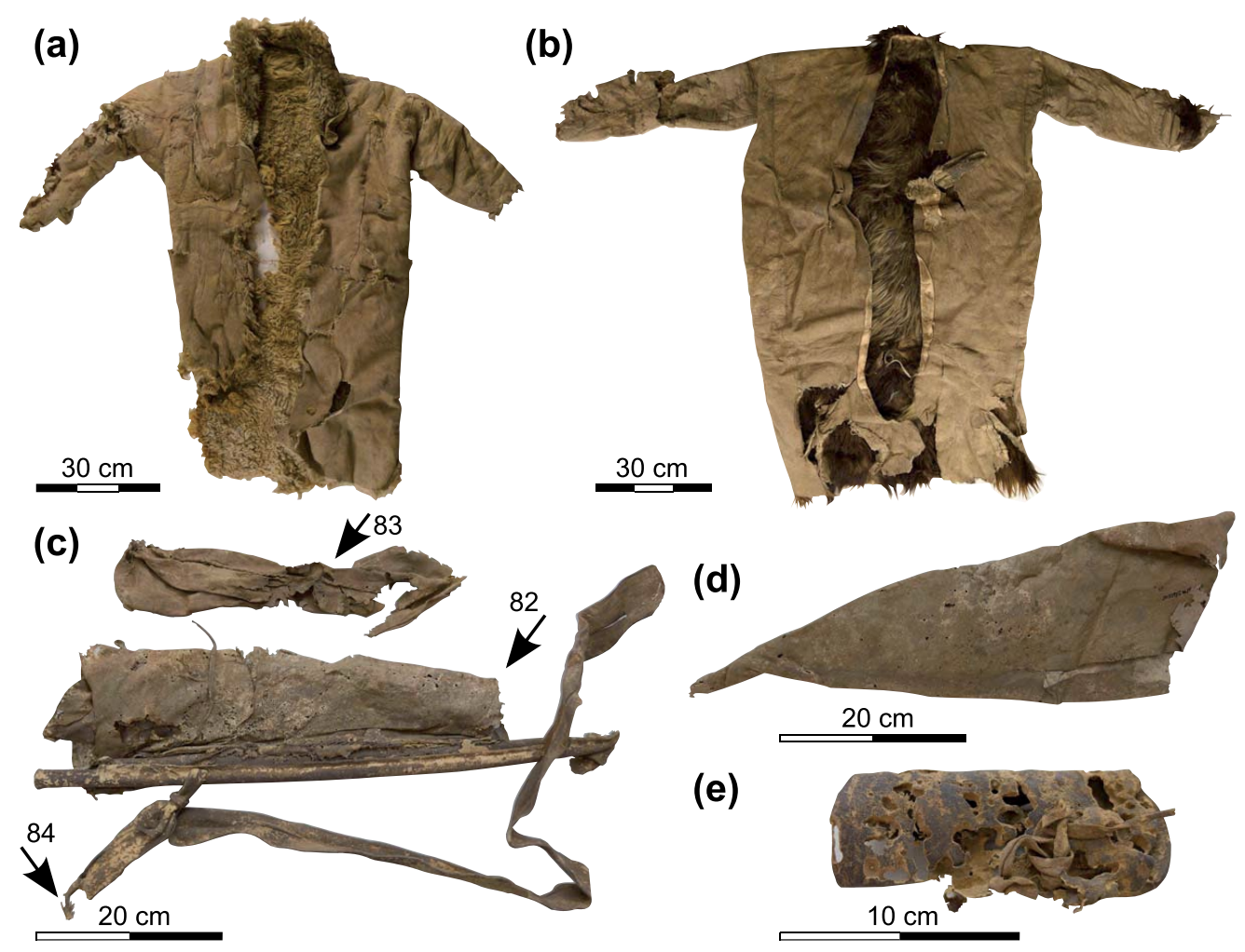

Figure 2. The five archaeological objects examined in this study (cf. Table I): (a) 86HWM:I-0075I; (b) 86HWM:2-00752; (c) 2003SAYIMI95:9 (arrows: original location of the three samples taken); (d) 2003SAYIMI95:10; (e) 2003SAYIMI95:I2 (scale bar in centimeters, all images by D Hosner, German Archaeological Institute).

line with the dates published earlier (Wang, 1999 and references therein). The 'old wood effect' (see Dong et al., 2014 for discussion of this problematic in northwestern China) cannot be significant as all our sampled trees were relatively young at their death. The horse bridle made of wood and leather from the 86HWM3 tomb of Wupu revealed an age between 1108 and 901 BC (95.4\% probability). This date indicates the presence of domesticated horses and horse riding in the Hami Oasis $c .3000$ years ago and corroborates the other evidence for early horse riding from the Turpan Oasis (Beck et al., 2014; Kramell et al., 2014) and the Kunlun Mountains (Wagner et al., 2011).

Hair of seven modern sheep and three goats were also sampled for comparison from two family farmsteads in Ya'erguolecun, Turpan, Xinjiang Uyghur Autonomous Region. The sheep of both farms belonged to an indeterminate breed of brown to black fattailed sheep used for felt production, some of which were horned. The goats belonged to a white, horned indeterminate dairy breed. The animals were almost certainly closely related.

\section{DNA extraction and amplification}

For ancient samples, all of the following procedures up to the first PCR set-up were performed in a dedicated ancient DNA lab, while PCR and post-PCR steps were performed in a separate laboratory, according to the recommendations of Cooper and Poinar (2000). Skin and leather samples were cut to pieces of approximately $3 \mathrm{~mm}$ by $3 \mathrm{~mm}$ depending on the shape of the original sample. DNA was extracted from these pieces according to established protocol (Dabney et al., 2013). Of each sample, at least two extractions were made with an additional mock extraction per three extractions. The species of each sample was first determined by amplifying three fragments $(107,106$, and $91 \mathrm{bp}$, respectively, including primers) located in the mitochondrial cytochrome $b$ gene (cytB) in a two-step multiplex PCR. The first PCR included all cytB primers (Table 3 ) and was conducted at a $10-\mu \mathrm{L}$ reaction volume containing $0.5 \mathrm{U}$ AmpliTaq Gold DNA Polymerase
(Thermo Fisher), $1 \times$ Buffer II (Thermo Fisher), $4 \mathrm{mM} \mathrm{MgCl}_{2}$, $0.25 \mathrm{mM} \mathrm{dNTP}, 1 \mathrm{mg} / \mathrm{mL}$ BSA, $0.075 \mu \mathrm{M}$ of each primer, and $2 \mu \mathrm{L}$ DNA extract. The resulting product was then re-amplified in a second PCR including only the two primers for a single fragment at a reaction volume of $20 \mu \mathrm{L}$ at the same concentrations except using $0.25 \mathrm{U}$ AmpliTaq Gold DNA Polymerase, $0.75 \mu \mathrm{M}$ of each primer, and $0.5 \mu \mathrm{L}$ product of the previous PCR. Both PCRs were run at initial denaturation of $94^{\circ} \mathrm{C}$ for $10 \mathrm{~min}$, at 30 cycles with $94^{\circ} \mathrm{C}$ for $30 \mathrm{~s}, 57^{\circ} \mathrm{C}$ for $45 \mathrm{~s}$, and $72^{\circ} \mathrm{C}$ for $45 \mathrm{~s}$, and a final extension at $72^{\circ} \mathrm{C}$ for $5 \mathrm{~min}$. The product of the second PCR was checked on a $3 \%$ agarose gel and sequenced on a $3130 \mathrm{XL}$ Genetic Analyzer (Applied Biosystems). After genera identification, specific primers (Table 3 ) were employed to amplify fragments of the mitochondrial control region (Ovis (sheep): three fragments 144, 140, and $140 \mathrm{bp}$ in length, Capra (goat) $170 \mathrm{bp}$, Bos (cattle) $177 \mathrm{bp}$ including primers) using the same concentrations and programs as before, except for sample 130417/84 where no BSA was added.

DNA from modern sheep and goat (hair samples) was extracted using the First Magnetic Forensic Kit (GEN-IAL) according to the manual. After extraction, only the second PCR step was performed for control region fragments, followed by Sanger sequencing as described before.

\section{DNA analysis}

Sequences were aligned in BioEdit. Haplogroups were identified with BLAST searches and comparison to reference sequences on DomeTree (Peng et al., 2015). For comparison, mitochondrial control region sequences from different geographical locations were downloaded from GenBank (sheep: KF938317-59, HM236176-77, JX235856; argali: HM236188, JX101654; urial: NC_026064, KF938361; Asiatic mouflon: NC_026063, KF938360, KF312238; goat: DQ089106-13,16,35,47,55-59,8688,91, AJ317760-1, EF617863-76, GQ342248, DQ847506-09, EF167788-802; Siberian ibex: NC 020626, FJ207529) to 
Table 2. AMS radiocarbon dates processed on samples from the Wupu and Yanghai tombs and discussed in this study. All dates were generated in the Poznan Radiocarbon Laboratory, Poland. The dates expressed in ${ }^{14} \mathrm{C} \mathrm{BP}$ (radiocarbon years before AD 1950, conventionally taken as the 'present') were converted to calendar years (BC) using OxCal v4.2.4 calibration software (Bronk Ramsey, 20I3) and atmospheric data from Reimer et al. (2013). Given are intervals of calendar ages, where the true ages of the samples encompass the probability ranges of $c .68 \%$ and c. 95\%. Radiocarbon-dated plant material identification has been done by R Neef. One leather sample (Sample ID I304I7/86) from the Yanghai tomb MI 95 disintegrated in chemical preparation almost completely, and extremely little amount of carbon $(0.01 \mathrm{mg})$ obtained from it did not allow for a reliable date. For this reason, the reported date $3400 \pm 170{ }^{14} \mathrm{C} \mathrm{BP}$ (Poz-76845) is regarded as 'very poor' and is not recommended for further use.

\begin{tabular}{|c|c|c|c|c|c|c|}
\hline Sample ID & $\begin{array}{l}\text { Laboratory } \\
\text { number }\end{array}$ & $\begin{array}{l}\text { Cemetery and } \\
\text { tomb number }\end{array}$ & $\begin{array}{l}\text { Dated material/ar- } \\
\text { chaeological context }\end{array}$ & $\begin{array}{l}\text { Radiocarbon date, } \\
{ }^{14} \mathrm{C} B P( \pm I \sigma)\end{array}$ & $\begin{array}{l}\text { Calibrated individual } \\
\text { dates, cal. BC }(68.2 \% \\
\text { probability })\end{array}$ & $\begin{array}{l}\text { Calibrated individual } \\
\text { dates, cal. BC ( } 95.4 \% \\
\text { probability) }\end{array}$ \\
\hline$|304| 4 / 36$ & Poz-57373 & $\begin{array}{l}\text { 86HWM:2-00752, } \\
\text { Wupu }\end{array}$ & $\begin{array}{l}\text { Barley (Hordeum vul- } \\
\text { gare) spikelets/leather } \\
\text { fur coat }\end{array}$ & $2515 \pm 30$ & $\begin{array}{l}775(15.4 \%) 747 \mathrm{BC} \\
685(10.4 \%) 666 \mathrm{BC} \\
642(42.4 \%) 555 \mathrm{BC}\end{array}$ & $\begin{array}{l}793(26.6 \%) 727 \mathrm{BC} \\
719(1.8 \%) 705 \mathrm{BC} \\
695(66.9 \%) 54 \mathrm{BC}\end{array}$ \\
\hline $1304 \mid 4 / 35$ & Poz-5737I & $\begin{array}{l}\text { 86HWM:2-00752, } \\
\text { Wupu }\end{array}$ & $\begin{array}{l}\text { Brome grass (Bromus } \\
\text { sp.) seeds/leather fur } \\
\text { coat }\end{array}$ & $2480 \pm 30$ & $\begin{array}{l}756(11.1 \%) 728 \mathrm{BC} \\
717(3.6 \%) 706 \mathrm{BC} \\
694(5.6 \%) 679 \mathrm{BC} \\
671(47.9 \%) 542 \mathrm{BC}\end{array}$ & $\begin{array}{l}774(94.9 \%) 482 \mathrm{BC} \\
44 \mathrm{I}(0.5 \%) 434 \mathrm{BC}\end{array}$ \\
\hline$|304| 4 / 37$ & Poz-57374 & $\begin{array}{l}\text { 86HWM:2-00752, } \\
\text { Wupu }\end{array}$ & $\begin{array}{l}\text { Non-identified } \\
\text { herbaceous plant } \\
\text { stem/thorn fragment/ } \\
\text { leather fur coat }\end{array}$ & $2470 \pm 30$ & $\begin{array}{l}753(27.1 \%) 682 \mathrm{BC} \\
669(20.8 \%) 612 \mathrm{BC} \\
593(20.3 \%) 538 \mathrm{BC}\end{array}$ & $\begin{array}{l}768(92.4 \%) 476 \mathrm{BC} \\
464(1.2 \%) 453 \mathrm{BC} \\
445(\mathrm{I} .8 \%) 43 \mathrm{I} \text { BC }\end{array}$ \\
\hline \multirow[t]{2}{*}{$|304| 4 / 38$} & Poz-57375 & $\begin{array}{l}\text { 86HWM:2-00752, } \\
\text { Wupu }\end{array}$ & $\begin{array}{l}\text { Burdock (Arctium sp.) } \\
\text { burr/leather fur coat }\end{array}$ & $2465 \pm 30$ & $\begin{array}{l}75 \mathrm{I}(26.9 \%) 683 \mathrm{BC} \\
669(12.4 \%) 636 \mathrm{BC} \\
626(3.5 \%) 614 \mathrm{BC} \\
592(25.4 \%) 516 \mathrm{BC}\end{array}$ & 764 (95.4\%) $430 \mathrm{BC}$ \\
\hline & $\begin{array}{l}\text { Combined } 4 \\
\text { dates }\end{array}$ & $\begin{array}{l}\text { 86HWM:2-00752, } \\
\text { Wupu }\end{array}$ & & & $\begin{array}{l}752(11.3 \%) 735 \mathrm{BC} \\
689(26.5 \%) 613 \mathrm{BC} \\
592(30.3 \%) 546 \mathrm{BC}\end{array}$ & $\begin{array}{l}762(19.1 \%) 705 \mathrm{BC} \\
695(76.3 \%) 54 \mathrm{BC}\end{array}$ \\
\hline$|304| 4 / 30$ & Poz-72755 & $\begin{array}{l}\text { 86HWM:I-0075 I, } \\
\text { Wupu }\end{array}$ & $\begin{array}{l}\text { Sewing wool thread/ } \\
\text { leather fur coat }\end{array}$ & $2500 \pm 30$ & $\begin{array}{l}767 \text { (II.1\%) } 744 \text { BC } \\
687(10.8 \%) 665 \text { BC } \\
644(46.4 \%) 552 \text { BC }\end{array}$ & 788 (95.4\%) 537 BC \\
\hline $1304 \mid 5 / 55$ & Poz-57377 & 86HWM3:I,Wupu & $\begin{array}{l}\text { Wood sample/ } \\
\text { wooden cheek-piece } \\
\text { of a horse bridle }\end{array}$ & $2825 \pm 30$ & $1012(68.2 \%) 927$ BC & 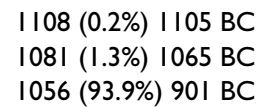 \\
\hline $1304 \mid 5 / 52$ & Poz-57378 & $\begin{array}{l}\text { 86HWMNN:I, } \\
\text { Wupu }\end{array}$ & $\begin{array}{l}\text { Blue wool thread/ } \\
\text { long robe }\end{array}$ & $2465 \pm 30$ & $\begin{array}{l}752(25.8 \%) 686 \mathrm{BC} \\
667(11.6 \%) 636 \mathrm{BC} \\
622(2.4 \%) 614 \mathrm{BC} \\
595(28.3 \%) 515 \mathrm{BC}\end{array}$ & $\begin{array}{l}760(27.8 \%) 682 \mathrm{BC} \\
671(56.7 \%) 480 \mathrm{BC} \\
469(10.9 \%) 414 \mathrm{BC}\end{array}$ \\
\hline $1304 \mid 6 / 79$ & Poz-5738I & $\begin{array}{l}\text { No tomb attribu- } \\
\text { tion, Wupu }\end{array}$ & $\begin{array}{l}\text { Wood/poplar trunk } \\
\text { from the tomb } \\
\text { chamber }\end{array}$ & $3050 \pm 30$ & $\begin{array}{l}\text { I385 (39.6\%) I33| BC } \\
\text { I326 (23.8\%) I I } 9 \text { | BC } \\
\text { I279 (4.8\%) I } 27 \mid \mathrm{BC}\end{array}$ & $\begin{array}{l}1409(92.7 \%) \quad 1258 \mathrm{BC} \\
1233(2.7 \%) \text { I } 218 \mathrm{BC}\end{array}$ \\
\hline $1304 \mid 6 / 80$ & Poz-57382 & $\begin{array}{l}\text { No tomb attribu- } \\
\text { tion, Wupu }\end{array}$ & $\begin{array}{l}\text { Wood/poplar trunk } \\
\text { from the tomb } \\
\text { chamber }\end{array}$ & $2715 \pm 35$ & 896 (68.2\%) 829 BC & 924 (95.4\%) 806 BC \\
\hline $1304 \mid 7 / 82$ & Poz-76927 & Yanghai, MI95 & $\begin{array}{l}\text { Leather fragment/ } \\
\text { bow and arrow } \\
\text { sheath }\end{array}$ & $2475 \pm 30$ & $\begin{array}{l}753(19.4 \%) 702 \mathrm{BC} \\
696(5.6 \%) 682 \mathrm{BC} \\
669(22.3 \%) 6 \mathrm{IIBC} \\
594(20.9 \%) 540 \mathrm{BC}\end{array}$ & $\begin{array}{l}77 \mathrm{I}(93.6 \%) 477 \mathrm{BC} \\
463(0.6 \%) 456 \mathrm{BC} \\
445(1.3 \%) 43 \mathrm{I} \mathrm{BC}\end{array}$ \\
\hline $1304 \mid 7 / 86$ & Poz-76845 & Yanghai, MI95 & $\begin{array}{l}\text { Leather fragment/ } \\
\text { bow and arrow } \\
\text { sheath }\end{array}$ & $\begin{array}{l}3400 \pm 170 \text { very poor } \\
\text { date, not used }\end{array}$ & $1916(68.2 \%) \mid 503$ BC & $\begin{array}{l}2197(0.8 \%) 2168 \mathrm{BC} \\
2149(92.9 \%) \quad 137 \mathrm{BC} \\
1359(1.8 \%) \quad 1299 \mathrm{BC}\end{array}$ \\
\hline
\end{tabular}

construct median-joining haplotype networks (Bandelt et al., 1999) using PopART 1.7 (Leigh, n.d.).

\section{Results}

\section{Ancient samples}

Sequences were recovered in five samples from Wupu and four samples from Yanghai (Table 1). One sample from Yanghai did not yield PCR products. In all successful amplifications from Wupu, both species and control region haplotype were recovered, while in the successful Yanghai amplifications the mitochondrial haplotype could only be determined in a single sample.

The three samples of the Wupu leather coat 86HWM:100751 were identified as sheep skin. One (130414/24) belongs to sheep haplogroup A while 130414/28 belongs to haplogroup
B; 130414/26 shows intermediate characteristics between haplogroups A and B. Only one sample from Yanghai, the bracer 2003SAYIM195:12 (130417/87), was amplifiable as a sheep control regional fragment (fragment 1), which corresponds to haplotype A1a.

Both samples from the Wupu leather coat, 86HWM:2-00752, were identified as goat-derived and belonged to goat haplogroup A, with $130414 / 33$ being closely related to haplotype A2 and $130414 / 34$ to $\mathrm{A} 3$.

The first cytB fragment of $130417 / 84$ shows two transitions that are not known from modern Bos taurus haplotypes and may not represent a domestic animal, but a wild aurochs or yak (Bos grunniens). Unfortunately the control region sequence has not been amplified successfully so far because of poor DNA quality. 
Table 3. PCR primers used in this study.

\begin{tabular}{|c|c|c|c|}
\hline Primer ID & Sequence $5^{\prime}-3^{\prime}$ & Length & Source \\
\hline \multicolumn{4}{|l|}{ cytB } \\
\hline I42f & GGCCTATTCCTAGCRATACAC & 21 & This study \\
\hline $248 r$ & TGTATRTATCGGATRATTCAGC & 22 & This study \\
\hline $395 f$ & TCYTACCATGAGGACAAATATC & 22 & This study \\
\hline $500 r$ & CCDCCTCAGATYCATTCGAC & 20 & This study \\
\hline 93 If & AARCAACGVAGCATRATATTCCG & 23 & This study \\
\hline $1022 r$ & GMCCTCCRATTCATGTRAGTG & 21 & This study \\
\hline \multicolumn{4}{|l|}{ Ovis ctr } \\
\hline LI539I & ССАСТATCAACACCCAAAG & 19 & Cai et al. (20II) \\
\hline HI5534 & AAGTCCGTGTTGTATGTTTG & 20 & Cai et al. (20II) \\
\hline OAUI5993 & GCATGTAGGGTATTAAACTGCTTGAC & 26 & Geörg (2013) \\
\hline OALI6087 & GATCCTTGCRYAGCGGGTTG & 20 & Geörg (2013) \\
\hline OAU16068 & CCAYTAGATCACGAGCTTGTTCAC & 24 & Geörg (2013) \\
\hline OALI6161 & CTGAAGAAAGAACCAGATGCCTGT & 24 & Geörg (2013) \\
\hline \multicolumn{4}{|l|}{ Capra ctr } \\
\hline CAP-FII & GATCTTCCYCATGCATATAAGCA & 23 & Fernández et al. (2006) \\
\hline CAP-RII & CGGGTTGCTGGTTTCAC & 17 & Fernández et al. (2006) \\
\hline \multicolumn{4}{|l|}{ Bos ctr } \\
\hline AnIF & CTTAATTACCATGCCGCGTG & 20 & Cai et al. (2014) \\
\hline An3R & CGAGATGTCTTATTTAAGAGG & 21 & Cai et al. (2014) \\
\hline
\end{tabular}

\section{Modern reference samples}

Control region sequences were recovered from seven sheep and three goats from Ya'erguolecun, China. Three sheep from one farm possessed haplotype A1c, one sheep from a second farm belonged to haplogroup A, while the other three belonged to haplogroup B. Two goats belonged to haplogroup A3, while one goat belonged to haplogroup A2.

\section{Discussion}

All successfully identified leather samples were derived from domestic animals. Neither wild sheep (argali Ovis ammon) nor wild goats (Siberian ibex Capra sibirica), which are both native to Central Asia, were found. The results show that all common domesticated bovids were used to produce leather in the sites of Wupu and Yanghai. Sheep, goat, and cattle were present in central and eastern Asia at least 5000 years ago (Cai et al., 2011, 2014; Lv et al., 2015; Payne and Hodges, 1997; Zhang et al., 2013).

Unfortunately, even after several repeats, mitochondrial haplotypes were not determined for most samples from the Yanghai site. This may be a result of different taphonomic conditions, which are less conductive for ancient DNA preservation, compared with Wupu or a result of different storage conditions in the respective museum collections, which have a significant influence on the success rate of ancient DNA analyses (Pruvost et al., 2007). Furthermore, among the leather objects from Wupu (coats), different tanning methods may have been employed compared with the objects from Yanghai (quivers and bracer).

\section{Sheep}

According to data from Lv et al. (2015), the first sheep entered eastern and northern China from the Caucasus, via Central Asia and the Mongolian Plateau around 6800-6400 years ago, with a second migratory wave around 4500 years ago. Today, the most common sheep mitochondrial haplogroups are A and $\mathrm{B}$, with $\mathrm{A}$ dominating in eastern and southern Asia, while B is the most common haplogroup in Europe and western Asia (Lv et al., 2015; Pedrosa et al., 2005; Tapio et al., 2006). Haplogroup C is common in fat-tailed breeds and may have entered China during the second migratory wave (Lv et al., 2015) while D and E are only found in southwest Asia (Tapio et al., 2006). Previously, this pattern was also found in an ancient DNA study (Cai et al., 2011) of east Chinese sheep remains from $c .4500$ to 1500 years ago, where A was the predominant haplogroup at $95.5 \%$.

The three sheep samples from Wupu belonged to haplogroups $\mathrm{A}, \mathrm{B}$, and an intermediate haplotype between the two, respectively. The control region sequence of $/ 24$ (A) has only one mutation difference with the most common A haplotype (Figure 3) which is common in modern Chinese sheep and was also found in one of the modern Turpan sheep. The control region sequence of /28 (B) was, overall, the most common in our dataset and is found in Europe, the Near East, and China (Figure 3). Three modern Turpan sheep shared the same sequence. The unusual intermediate control region sequence of $/ 26$ was previously found in modern sheep from Pakistan (JX235856) and Italy (JN184935) (Pariset et al., 2011) but is unknown from modern China.

Our findings show that a certain degree of diversity was present in domesticated sheep from the Wupu site, as both haplogroups A and B were present in a small sample. Haplogroup C was not detected, which could imply that the sheep from which the leather was derived did not belong to the ancestors of the modern fat-tailed breeds (Lv et al., 2015). However, none of the sampled modern Turpan fat-tailed sheep showed this haplotype either, so this prediction is questionable. The similarities of the control region sequences between ancient samples and modern Turpan and other Chinese breeds indicate a continuity of sheep husbandry in the Turpan Oasis from the 1st millennium BC to modern times.

\section{Goat}

Most likely, the first domesticated goats entered eastern Asia at the same time as sheep. Modern goat mitochondrial haplotype diversity is dominated by haplogroup A with a global preponderance of over 90\% (Luikart et al., 2001; Naderi et al., 2007), which may correspond to the first wave of migration of early domestics from the center of origin of domestication in the Near East (Akis et al., 2014; Luikart et al., 2001). In eastern Asia, haplogroup B is also present in moderate numbers ( $25 \%$ ) (Chen et al., 2005 ; Liu et al., 2009) and was found in ancient European and Chinese goats (Fernández et al., 2006; Han et al., 2010) while haplogroups $\mathrm{C}-\mathrm{D}$ are rare worldwide. In this context, it is not surprising that 


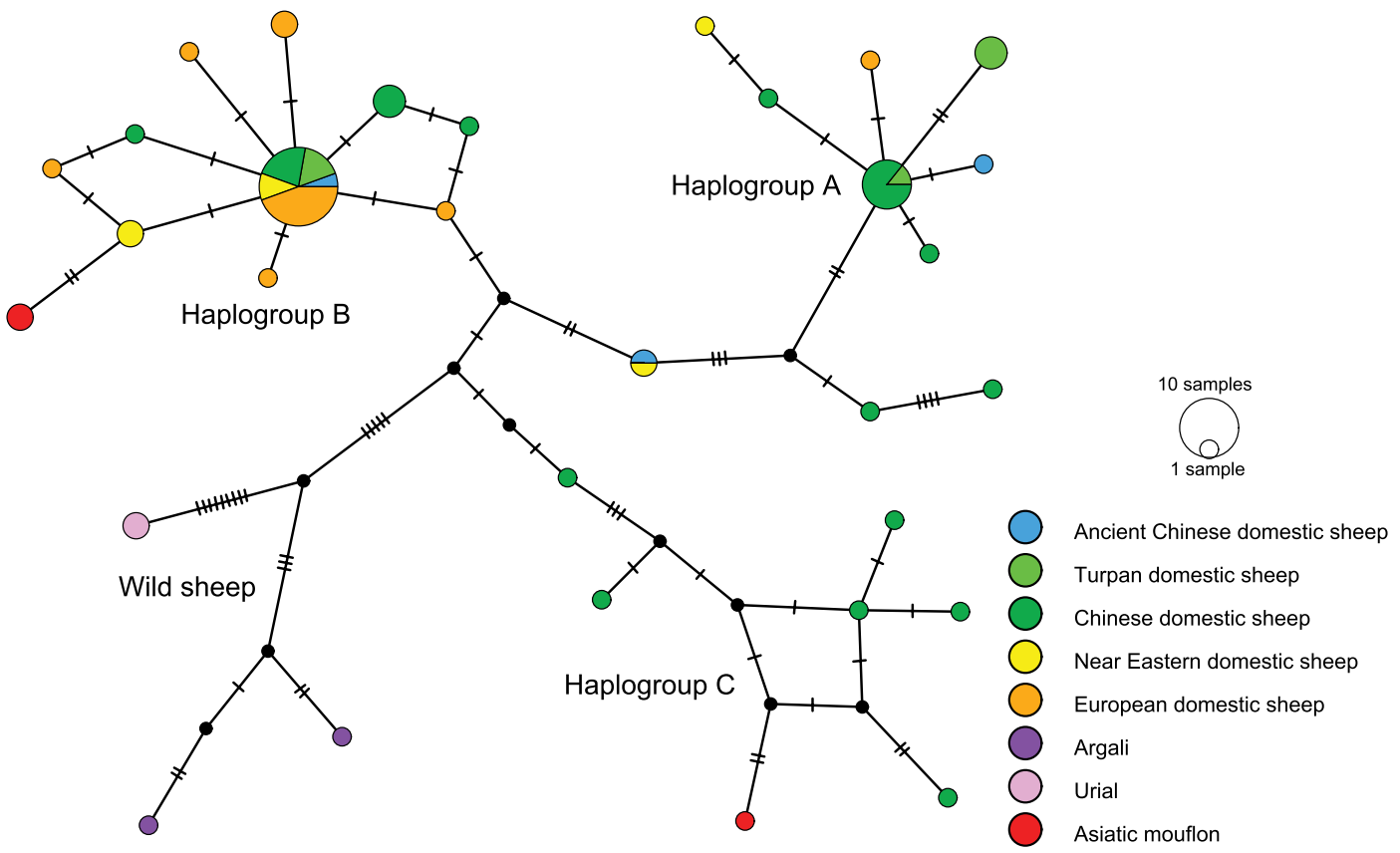

Figure 3. Median-joining haplotype network of the control region fragments of 58 ancient and modern sheep.Ancient Chinese sheep denote results from leather samples of this study. Turpan sheep are modern sheep sampled from two farms close to the archaeological sites of this study.

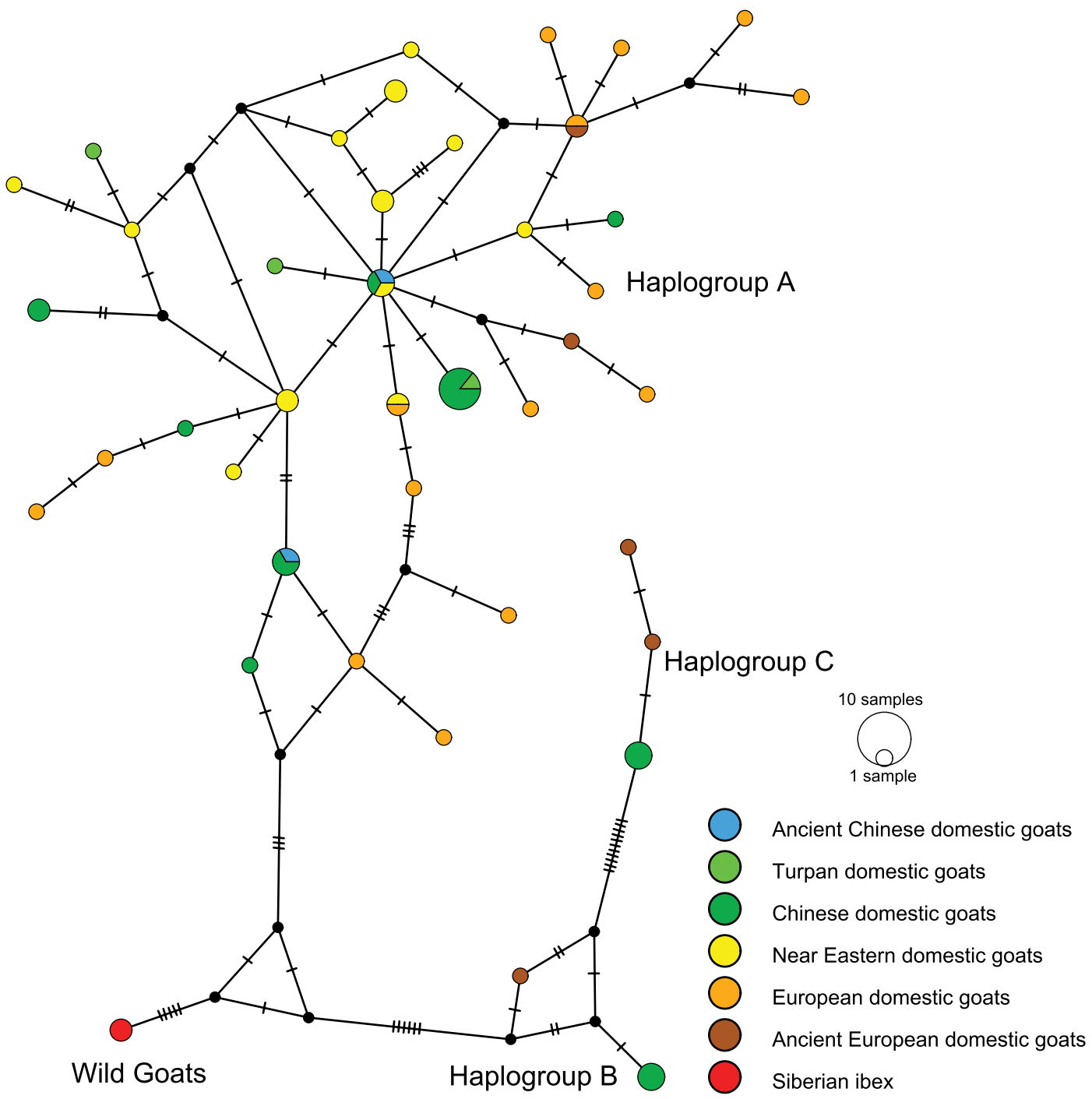

Figure 4. Median-joining haplotype network of the amplified control region fragments of 62 ancient and modern goats. Ancient Chinese goats denote results from leather samples of this study. Turpan goats are modern goats sampled from two farms close to the archaeological site of this study. 
both goat-derived leather samples from Wupu belonged to the most common haplogroup A. Both sequences were previously found in modern Chinese domesticated goats (/33:DQ089113, DQ089147, and /34:DQ089186). Accordingly, modern goats from Turpan also belonged to this haplogroup with two individuals being particularly close to $/ 34$, each differing by only one transition (Figure 4). As in sheep this implies a continuity of goat farming in the Turpan Oasis.

\section{Conclusion}

Our results show that domestic sheep, goat, and cattle were present and used for leather production in the Turpan and Hami oases around c. 2800-2500years ago. Based on the directly dated cheek-piece from Wupu, the domesticated horse and horse riding in the Hami region can be dated to $c$. 1100-900 BC. The mitochondrial control region sequences of ancient sheep and goats are identical or closely related to modern domesticated animals from the same geographic region and other parts of China, pointing to a continuity of pastoralism with the same general stock of animals to the present. Wild ungulates apparently did not play an important role for the production of leather garments and gear in the Bronze Age communities of Wupu and Yanghai, emphasizing the importance of animal husbandry. Our results demonstrate that ancient DNA methods are valuable for identifying species and lineages of Central Asian domesticated animals from archaeological leather remains.

\section{Acknowledgements}

The authors acknowledge gratefully the work of Chinese colleagues who excavated and preserved the objects in Turpan and Hami and who shared in the discussion of the archaeological context. Thanks to P Wertmann, XC Chen, and D Hosner for their help in organizing fieldwork campaigns, providing photos, and translation from Chinese and to D Lieckfeldt for assisting in lab work and primer design. We also thank Dr R Spengler for editorial corrections and valuable suggestions and two anonymous reviewers for their helpful comments which we considered in the revised version of this manuscript.

\section{Funding}

This study is a contribution to the 'Silk Road Fashion' research project supported by the German Federal Ministry of Research and Education (Grant 01UO1310) and the German Archaeological Institute.

\section{References}

Akis I, Onar V, Toker N et al. (2014) Ancient DNA analysis of Anatolian goat remains excavated from a Urartian castle in eastern Turkey. International Journal of Osteoarchaeology. Epub ahead of print 25 August. DOI: 10.1002/oa.2415.

Bandelt HJ, Forster P and Röhl A (1999) Median-joining networks for inferring intraspecific phylogenies. Molecular Biology and Evolution 16(1): 37-48.

Beck U, Wagner M, Li X et al. (2014) The invention of trousers and its likely affiliation with horseback riding and mobility: A case study of late 2nd millennium BC finds from Turfan in eastern Central Asia (The Bridging Eurasia Research Initiative: Modes of mobility and sustainability in the palaeoenvironmental and archaeological archives from Eurasia). Quaternary International 348: 224-235.

Brandt LØ, Tranekjer LD, Mannering U et al. (2011) Characterising the potential of sheep wool for ancient DNA analyses. Archaeological and Anthropological Sciences 3(2): 209-221.

Bronk Ramsey C (2013) OxCal Program v4.2.4. Oxford: Radiocarbon Accelerator Unit, University of Oxford.
Cai D, Sun Y, Tang Z et al. (2014) The origins of Chinese domestic cattle as revealed by ancient DNA analysis. Journal of Archaeological Science 41: 423-434.

Cai D, Tang Z, Yu H et al. (2011) Early history of Chinese domestic sheep indicated by ancient DNA analysis of Bronze Age individuals. Journal of Archaeological Science 38(4): 896-902.

Chen SY, Su YH, Wu SF et al. (2005) Mitochondrial diversity and phylogeographic structure of Chinese domestic goats. Molecular Biology and Evolution 37: 804-814.

Cooper A and Poinar HN (2000) Ancient DNA: Do it right or not at all. Science 289(5482): 1139.

Dabney J, Knapp M, Glocke I et al. (2013) Complete mitochondrial genome sequence of a Middle Pleistocene cave bear reconstructed from ultrashort DNA fragments. Proceedings of the National Academy of Sciences of the United States of America 110(39): 15758-15763.

Domrös M and Peng G (1988) The climate of China. Berlin: Springer.

Dong G-H, Wang Z-L, Ren L-L et al. (2014) A comparative study of ${ }^{14} \mathrm{C}$ dating on charcoal and charred seeds from Late Neolithic and Bronze Age sites in Gansu and Qinghai provinces, NW China. Radiocarbon 56(1): 157-163.

Fernández H, Hughes S, Vigne J-D et al. (2006) Divergent mtDNA lineages of goats in an Early Neolithic site, far from the initial domestication areas. Proceedings of the National Academy of Sciences of the United States of America 103(42): 15375-15379.

Geörg C (2013) Paläopopulationsgenetik von Schwein und Schaf in Südosteuropa und Transkaukasien. Dissertation, German Archaeological Institute.

Guojia Wenwuju (2012) Zhongguo wen wu di tu ji: Xinjiang Weiwu'er zizhiqu fen ce [Atlas of Chinese Cultural Relics: Xinjiang Uyghur Autonomous Region Volume]. Beijing: Cultural Relics Publishing House.

Han L, Yu H-X, Cai D-W et al. (2010) Mitochondrial DNA analysis provides new insights into the origin of the Chinese domestic goat. Small Ruminant Research 90(1-3): 41-46.

Hofreiter M, Paijmans JLA, Goodchild H et al. (2015) The future of ancient DNA: Technical advances and conceptual shifts. Bioessays 37: 284-293.

Jiang H-E, Li X, Ferguson DK et al. (2007) The discovery of Capparis spinosa L. (Capparidaceae) in the Yanghai Tombs (2800 years B.P.), NW China, and its medicinal implications. Journal of Ethnopharmacology 113: 409-420.

Jiang H-E, Li X, Zhao Y-X et al. (2006) A new insight into Cannabis sativa (Cannabaceae) utilization from 2500-year-old Yanghai Tombs, Xinjiang, China. Journal of Ethnopharmacology 108: 414-422.

Jiang H-E, Zhang Y-B, Li X et al. (2009) Evidence for early viticulture in China: Proof of a grapevine (Vitis vinifera L., Vitaceae) in the Yanghai Tombs, Xinjiang. Journal of Archaeological Science 36(7): 1458-1465.

Kramell A, Li X, Csuk R et al. (2014) Dyes of late Bronze Age textile clothes and accessories from the Yanghai archaeological site, Turfan, China: Determination of the fibers, color analysis and dating (The Bridging Eurasia Research Initiative: Modes of mobility and sustainability in the palaeoenvironmental and archaeological archives from Eurasia). Quaternary International 348: 214-223.

Leigh J (n.d.) PopART website. Available at: http://popart.otago. ac.nz (accessed 8 December 2015).

Li C, Li H, Cui Y et al. (2010) Evidence that a West-East admixed population lived in the Tarim Basin as early as the early Bronze Age. BMC Biology 8: 15.

Li C, Lister DL, Li H et al. (2011) Ancient DNA analysis of desiccated wheat grains excavated from a Bronze Age cemetery in Xinjiang. Journal of Archaeological Science 38: 115-119. 
Liu Y-P, Cao S-X, Chen S-Y et al. (2009) Genetic diversity of Chinese domestic goat based on the mitochondrial DNA sequence variation. Journal of Animal Breeding and Genetics 126: 80-89.

Luikart G, Gielly L, Excoffier L et al. (2001) Multiple maternal origins and weak phylogeographic structure in domestic goats. Proceedings of the National Academy of Sciences of the United States of America 98: 5927-5932.

Lv F-H, Peng W-F, Yang J et al. (2015) Mitogenomic metaanalysis identifies two phases of migration in the history of eastern Eurasian sheep. Molecular Biology and Evolution 32: 2515-2533.

Naderi S, Rezaei H-R, Taberlet P et al. (2007) Large-scale mitochondrial DNA analysis of the domestic goat reveals six haplogroups with high diversity. PLoS ONE 2(10): e1012.

Pariset L, Mariotti M, Gargani M et al. (2011) Genetic diversity of sheep breeds from Albania, Greece, and Italy assessed by mitochondrial DNA and nuclear polymorphisms (SNPs). The Scientific World Journal 11: 1641-1659.

Payne WJA and Hodges J (1997) Tropical Cattle: Origins, Breeds and Breeding Policies. Oxford; Malden, MA: Blackwell Science Ltd.

Pedrosa S, Uzun M, Arranz J-J et al. (2005) Evidence of three maternal lineages in near eastern sheep supporting multiple domestication events. Proceedings of the Royal Society of London B: Biological Sciences 272(1577): 2211-2217.

Peng M-S, Fan L, Shi N-N et al. (2015) DomeTree: A canonical toolkit for mitochondrial DNA analyses in domesticated animals. Molecular Ecology Resources 15(5): 1238-1242.

Poulakakis N, Tselikas A, Bitsakis I et al. (2007) Ancient DNA and the genetic signature of ancient Greek manuscripts. Journal of Archaeological Science 34(5): 675-680.

Pruvost M, Schwarz R, Correia VB et al. (2007) Freshly excavated fossil bones are best for amplification of ancient DNA. Proceedings of the National Academy of Sciences of the United States of America 104(3): 739-744.
Reimer PJ, Bard E, Bayliss A et al. (2013) IntCal13 and Marine13 radiocarbon age calibration curves $0-50,000$ years cal BP. Radiocarbon 55(4): 1869-1887.

Schlumbaum A, Campos PF, Volken S et al. (2010) Ancient DNA, a Neolithic legging from the Swiss Alps and the early history of goat. Journal of Archaeological Science 37(6): 1247-1251.

Tapio M, Marzanov N, Ozerov M et al. (2006) Sheep mitochondrial DNA variation in European, Caucasian, and Central Asian areas. Molecular Biology and Evolution 23(9): 1776-1783.

Teasdale MD, van Doorn NL, Fiddyment S et al. (2015) Paging through history: Parchment as a reservoir of ancient DNA for next generation sequencing. Philosophical Transactions of the Royal Society of London Series B: Biological Sciences 370(1660): 20130379.

Vuissoz A, Worobey M, Odegaard N et al. (2007) The survival of PCR-amplifiable DNA in cow leather. Journal of Archaeological Science 34(5): 823-829.

Wagner M, Bo W, Tarasov P et al. (2009) The life-history of the warrior-and-centaur trousers from Sampula (Xinjiang, China). Antiquity 83: 1065-1075.

Wagner M, Wu X, Tarasov P et al. (2011) Radiocarbon-dated archaeological record of early first millennium B.C. mounted pastoralists in the Kunlun Mountains, China. Proceedings of the National Academy of Sciences of the United States of America 108(38): 15733-15738.

Wang BH (1999) Xinjiang gu shi [The ancient corpses of Xinjiang]. Ürümqi: Xinjiang Renmin Chubanshe.

Xinjiang tu lu fan xue yan jiu yuan and Xinjiang wen wu kao gu yan jiu suo (2011) Xinjiang Shanshan Yanghai mu di fa jue bao gao. Kaogu Xuebao 1: 99-150.

Zeder MA (2008) Domestication and early agriculture in the Mediterranean Basin: Origins, diffusion, and impact. Proceedings of the National Academy of Sciences of the United States of America. Epub ahead of print 27 May. DOI: 10.1073/ pnas.0801317105.

Zhang H, Paijmans JLA, Chang F et al. (2013) Morphological and genetic evidence for early Holocene cattle management in northeastern China. Nature Communications 4: 2755. 